\title{
Common Agricultural Policy support, technical efficiency and productivity change in French agriculture
}

\author{
Laure Latruffe $^{1}$ - Yann Desjeux ${ }^{1}$
}

Received: 5 November 2013 / Accepted: 19 May 2015 / Published online: 4 May 2016

(C) The Author(s) 2016. This article is published with open access at Springerlink.com

\begin{abstract}
This paper investigates how the various changes in the policy supporting agriculture in the European Union, i.e. the Common Agricultural Policy (CAP), and various types of subsidies (investment, production and rural development) affected the technical efficiency and productivity change of farms in France between 1990 and 2006. Three types of farming-field crop, dairy and beef cattle-are considered. Comparison of efficiency across periods indicates a significant reduction in efficiency in the period following the first CAP reform (1992 MacSharry reform) but an improvement in efficiency change. Econometric results related to the effect of subsidies on efficiency scores (with fixed effect models) and productivity change indices (with ordinary least squares) give ambiguous findings. The effect of a particular type of subsidy was found to be negative or positive depending on the sample's production orientation and on the performance considered. Several methodological recommendations are drawn from the analysis for future research.
\end{abstract}

Keywords Farms · Technical efficiency · Malmquist indices · Common Agricultural Policy · Subsidies · France

JEL classification D24 · Q12 · Q18

Laure Latruffe

laure.latruffe@rennes.inra.fr

1 SMART, INRA, 35000 Rennes, France

\section{Introduction}

This paper investigates how the various changes in the policy supporting agriculture in the European Union (EU)-the Common Agricultural Policy (CAP) - and the different types of farm subsidies affected the technical efficiency (TE) of farms in France during 1990-2006.

Over the past two decades, the CAP has undergone major changes. Three main reforms were undertaken, all with the objective of modifying the way European farms benefit from public support. There has been a gradual shift from 'coupled' support, i.e. support given per unit of output, to more 'decoupled' support, which is not related to production but given on an area or as income support. The first decoupled subsidies, namely crop area and livestock direct payments, were introduced in the first CAP reform in 1992 (the MacSharry reform), while price support for specific types of production was reduced. However, these direct payments were still linked to production decisions, since they concerned only land sown with specific crops or supporting specific livestock types. The first agri-environmental payments (AEPs), provided to farmers who comply with environmental commitments on a voluntary basis, were also introduced. AEP and payments for farms located in less-favoured areas (LFA) are part of rural development payments. In the following reform in 2000, the so-called Agenda 2000, additional types of crop area and livestock became eligible for the direct payments, and rural development payments were strengthened. The Luxembourg CAP reform of 2003 introduced a fully decoupled support instrument called the Single Farm Payment (SFP), which is an income support scheme provided per hectare under any type of production, or even for land not in production, but which is dependent on compliance with environmental prescriptions (crosscompliance). 
Theoretically, it is difficult to draw a priori expectations of the effects of subsidies. Bergström (2000) and Martin and Page (1983) proposed that subsidies would have a negative effect on TE as a result of reduced effort by managers. More recently, and applied to the agricultural sector, Serra et al. (2008) suggested that risk effects shape the relationship between subsidies and TE. According to these authors, from a theoretical point of view, it is not possible to draw unambiguous conclusions concerning the connection between subsidies and TE because this depends on farmers' risk attitudes and on whether the inputs affected are risk- increasing or riskdecreasing. Therefore, Serra et al. (2008) recommended resorting to empirical investigations.

Several papers have analysed empirically how the agricultural subsidies received by farms alter the farm's TE. Examples include the following: Giannakas et al. (2001) for crop farms in Saskatchewan during 1987-1995; Rezitis et al. (2003) for Greek farms in 1993 and 1997; Hadley (2006) for eight different production types of farms in England and Wales during 1982-2002; Emvalomatis et al. (2008) for Greek cotton farms during 1996-2000; Zhu and Oude (2010) for crop farms in Germany, the Netherlands and Sweden during 1995-2004; Zhu et al. (2011) for Greek olive farms in the period 1995-2004; Nastis et al. (2012) for alfalfa production in Greece in 2008; Kumbhakar et al. (2014) for Norwegian crop farms in 2004-2008; and Sipiläinen et al. (2014) for Finnish and Norwegian dairy farms in 19912008. For the EU's new Member States, studies include the following: Bojnec and Latruffe (2009) for Slovenian farms during 1994-2003; Latruffe and Fogarasi (2009) for French and Hungarian dairy and field crop farms during 2001-2004; and Bakucs et al. (2010) for Hungarian farms during 20012005. The general conclusion of existing studies is that the effect of subsidies on TE is negative. On occasion, evidence of a positive effect has been given, such as Hadley (2006) who found a positive impact for the particular case of dairy and beef farms in England and Wales during 1982-2002. In their meta-analysis, Minviel and Latruffe (2014) suggested that the direction of the effect of subsidies on TE depends on the type of subsidy considered.

This paper aims at contributing to the debate by investigating whether various types of subsidies have a similar impact on farms' TE. Hence, contrary to most of the existing research which concentrates on either all subsidies received by farms or on one single type of subsidy, here, we investigate the impact of three distinct types of subsidies: (i) subsidies to carry out investments on the farm; (ii) subsidies linked to production; and (iii) subsidies received under the framework of rural development actions.

In addition to investigating the influence of subsidies on yearly TE, their influence on the change in TE is also investigated, along with their influence on technological change and on the resulting total productivity change. This issue has been investigated less frequently than the TE- subsidy link. While some studies have focused on assessing the impact of subsidies on productivity as a whole (e.g. Mary, 2013, Rizov et al. 2013), few have considered the decomposition of productivity into TE change and technological change. In France, Guyomard et al. (2006) found that, despite the negative influence of subsidies on yearly TE, the influence was positive on TE change and total productivity change for all three types of farms considered (crop, dairy, beef cattle) and on technological change for crop farms during 1995-2002. For three other EU countries (Germany, the Netherlands and Sweden), Zhu and Oude Lansink (2010) reported a negative effect of subsidies on the TE change of crop farms. Using village-level data in China for the period 1995-2009, Zheng and Kening (2011) showed that subsidies had a positive influence on TE change, technological change and total productivity change.

The paper is structured as follows. The second section explains the methodology, while Section 3 describes the data. Section 4 presents and discusses the results, and the fifth section concludes.

\section{Methodology}

\section{Computation of technical efficiency scores and productivity change indices}

In this research, the non-parametric approach data envelopment analysis (DEA) is used (Farrell, 1957; Charnes et al., 1978). DEA constructs a piece-wise frontier that envelops all observations in the sample used, so that the best performing farms form the envelope (i.e. the frontier) and the distance from poorly performing farms to the frontier represents their inefficiency. The further a farm is from the frontier, the less efficient it is, while farms on the frontier are fully efficient. Fully efficient farms are given a score of 1, while inefficient farms have scores lower than 1, with lower scores indicating lower efficiency.

One advantage of DEA is that it can disentangle TE due purely to management practices (the so-called pure TE; PTE) from scale effects (scale efficiency, SE, being the residual between TE and PTE). The main weakness of DEA is that, since the farms in the sample are used to construct the enveloping efficient frontier, results might be affected by sample bias in such a way that efficiency is overestimated if the best performing farms of the population are not included in the sample used. Thus, in this paper, we correct TE and PTE DEA scores for sample bias using the bootstrap method introduced by Simar and Wilson $(1998,2000)$. This method simulates the data distribution by imitating the data generating process. In practice, the approach relies on creating pseudo-data and implementing DEA on this new dataset. Repeating these steps numerous times enables the true distribution to be 
approximated and hence inference results can be produced. It should be noted, however, that after correction for bias, the corrected DEA scores are lower than the original DEA scores (which are overestimated as explained above), and hence, no farm in the sample still has an efficiency score of 1 .

A further weakness of DEA is that the shape of the frontier and therefore efficiency scores are affected by the presence of extreme data. For this reason, in our research, prior to any efficiency calculation, outliers were eliminated using the method introduced by Wilson (1993). This approach calculates a log ratio that compares the geometric volume of the whole dataset to the volume spanned by a subset of data. The outlier detection method then consists of a graphical analysis, whereby outliers are identified when the log ratio is high for a specific subset of data.

The change in TE between 2 years is calculated with the help of Malmquist productivity indices (Caves et al., 1982; Färe et al., 1992), corrected for sample bias using bootstrapping (Simar and Wilson, 1999). These give, for each farm, the change in total productivity between year $t$ and year $t+1$ by comparing the location of the farm with respect to the efficient frontier in each of the 2 years. The Malmquist (total) productivity index can then be decomposed into two components: the technological change index, which assesses the move of the frontier over time, and the TE change index, which evaluates the change in TE. The latter can also be decomposed into change in PTE and change in SE. Hence, five productivity change indices are computed here (TE change index, PTE change index, SE change index, technological change index and Malmquist total productivity change index). All indices are interpreted as follows: a value of one indicates no change, while a value above one indicates progress or growth. A value below one indicates decrease or deterioration.

The output-oriented DEA model includes one single output - the value, in real terms, of the farm's total output in euros - and four inputs: utilised agricultural area (UAA) in hectares; total labour used on the farm in annual working units (AWUs; where $1 \mathrm{AWU}$ corresponds to $2200 \mathrm{~h}$ of labour per year); the value, in real terms, of the farm's fixed assets in euros; and the value, in real terms, of intermediate consumption in euros. ${ }^{1}$ Yearly frontiers are built, and separate frontiers are constructed for farms with different production

\footnotetext{
${ }^{1}$ Consumer price indices from Eurostat with 1990 as the base year were used to express all values in real terms (this concerns output, fixed assets, intermediate consumption and subsidies). The use of the same index to deflate outputs as well as inputs is based on the assumption that their price series have similar developments over the period considered, which is a potentially strong assumption. However, farms are treated equally here, which is consistent with the idea that they probably face the same price changes. In any case, using price indices introduces errors since the individual prices faced by farms are not known.
}

specialisations: crop farms, dairy farms and beef cattle rearing and fattening farms.

\section{Analysis of the impact of subsidies}

When farm-level data are used, the method commonly employed by researchers to assess the impact of subsidies on farm efficiency is a regression of efficiency scores on a variable representing the farms' dependence on subsidies. ${ }^{2}$ In the literature, this is proxied either by the value of total subsidies received, or by the share of farm income stemming from government support, or by a ratio relating the amount of subsidies to the level of output or gross margin in order to control for size effects.

Another approach may also be found in the literature. Instead of an econometric regression, some research has compared the evolution of farm level efficiency across several periods that differed in terms of agricultural policy (for example Lachaal, 1994; Paul et al., 2000; Coelli et al., 2006; Carroll et al., 2009). In the present paper both approaches, i.e. a comparison of periods and an econometric analysis, are used.

For the comparison of period approach, we use statistical tests $^{3}$ to test the significance of the difference between efficiency means across four different periods of CAP reforms:

1. Period 1, 1990-1994, is the benchmark period, i.e. when price support was the order of the day and before any CAP reform.

2. Period 2, 1995-1999, is the period where the effect of the first CAP reform is investigated (the MacSharry reform was agreed in 1992, but in France, its full implementation was completed only in 1995).

3. Period 3, 2000-2005, represents the period following the second CAP reform (Agenda 2000).

4. Period 4, 2006, is the first year of implementation of the Luxembourg 2003 CAP reform in France. It should be noted that this period is not considered in the case of productivity change indices, since 2 years are necessary to calculate the indices.

\footnotetext{
${ }^{2}$ Simar and Wilson (2007) criticised this two-stage approach where DEA scores are calculated in the first stage and scores are explained in a second-stage regression. The authors raised the problem of serial correlation among scores and proposed a double bootstrapping procedure to account for this. However, this proposal has not been widely followed and the literature on the determinants of efficiency still mainly relies on the two-stage approach. Indeed, Latruffe et al. (2008) showed for a sample of Czech farms that both approaches (the traditional two-stage approach and the double bootstrap approach) produced similar results.

${ }^{3}$ The tests of comparison used are $t$ tests when the distribution of scores is normal, and Mann-Whitney tests otherwise. Normality is explored through Q-Q plots.
} 
For the econometric approach, determinants of efficiency are investigated with regressions where the dependent variable is either the farms' TE score, or PTE score, or SE score (three regressions per farm sample). ${ }^{4}$ Panel data regressions are used, where individual effects enable heterogeneity across farms and omitted variables that are specific to each farm and time-invariant to be accounted for. $F$ tests confirmed that fixed individual effect specification is preferred to pool ordinary least squares (OLS) by rejecting the null hypothesis of absence of fixed effects.

The explanatory variables include the levels of the various types of subsidy received by farms, aggregated into three categories: (i) investment subsidies; (ii) production subsidies; and (iii) rural development subsidies. Investment subsidies are received to implement specific investments on the farm. Production subsidies are subsidies linked to agricultural production. The category used here consists of area payments for specific crops cultivated, payments per animal for specific livestock bred and the decoupled SFP. It is up to each EU Member State to decide which types of crop and livestock are subsidised with per-unit payments. During the period considered, French farmers could receive such payments for land cultivated with cereal, oilseed and protein crops and for breeding beef and sheep. The rural development subsidies considered here consist of AEP and LFA payments. The design of AEP is also at the Member State's discretion. In France during this period, AEP mainly targeted the mitigation of nitrogen leaching by reducing a farm's livestock density and/or nitrogen inputs to crops and promoted the development of grazing livestock systems and the conversion to organic farming. Production subsidies and rural development subsidies together make operational subsidies, that is to say subsidies provided for current farm operations, in contrast to investment subsidies. The values of the production subsidies and the values of rural development subsidies are incorporated in the regression models in real terms as ratios, i.e. per hectare of UAA (for crop farms) or per livestock equivalent unit (for livestock farms) in order to control for size effects. Since only a few farms received investment subsidies, the explanatory variable used is not the farm's value of the subsidies, but a dummy variable taking the value one if the farm received some investments subsidies, and zero if it received none.

Other explanatory variables include the following: yearly dummies; regional dummies to control for other localisation effects; ${ }^{5}$ an extensification proxy for farms specialising in

\footnotetext{
${ }^{4}$ As explained above, due to bootstrapping, the distributions of TE scores and of PTE scores are not truncated at one. Regarding SE scores, the low shares of farms with an SE score of one (2.6, 3.6 and $7.5 \%$ for the field crop, dairy farm and beef cattle samples, respectively) did not imply the need to resort to truncated regressions.

${ }^{5}$ Namely 20 administrative regional dummies at the NUTS2-level of the European territorial classification NUTS (see http://ec.europa.eu/eurostat/ statistics-explained/index.php/Glossary:Nomenclature of territorial units_for_statistics_\%28NUTS\%29).
}

livestock production, namely the number of UAA hectares available per livestock unit; and two dummies classifying farms according to their size. In agriculture, there is no consensus on a single indicator for farm size, since it depends on the types of production and technology used on the farm (Carlin and Crecink, 1979; Lund, 1983). For this reason, three farm clusters are created on the basis of four size indicators: ${ }^{6}$ UAA; total labour used on the farm; number of livestock equivalent units on the farm; and the value of fixed assets in real terms. In order to avoid small coefficients in the econometric results, all subsidy variables are given in thousand euros per hectare or per livestock unit, and the extensification variable is given in hundred hectares per livestock unit.

Determinants of either productivity change index are investigated with OLS regressions (five regressions per farm sample). Individual effect specifications were tested but rejected by the tests. It should be noted that the explanatory variables that explain an index of change between period $t$ and period $t+1$ are the ones observed in period $t$.

\section{Data}

The farm-level data used for the period 1990-2006 were extracted from the EU Farm Accountancy Data Network (FADN) database. This database consists of yearly accounting data for commercial farms, rotating over a 5 -year period at the maximum. We categorised farms according to their product specialisation since technology differs across specialisations, and the type and amount of subsidies differed depending on the farms' production specialisation. We focused specifically on three groups of farms depending on their production specialisation, based on the EU standard classification of 'Type of Farming' (TF). The criterion for farms' classification is that at least $66 \%$ of their gross margin must come from the specific production of the TF. Here, the analyses are carried out for field crop farms (TF1), dairy farms (TF41) and beef cattle rearing and fattening farms (TF42). Only farms appearing in the FADN database for at least two consecutive years are kept for the analyses, so that Malmquist indices can be calculated. The three samples used in this paper are therefore unbalanced panels.

Table 1 presents some descriptive statistics of the data used. During the period studied, on average, dairy farms were just over half the size of field crop farms (62.6 vs. 120.7 ha), but used as much labour (1.68 vs. 1.67 AWU). Beef cattle farms used, on average, the least labour of all three specialisations (1.46 AWU) but had the highest fixed asset value. Regarding

\footnotetext{
${ }^{6}$ Farms are partitioned with K-means algorithm where the number of groups (clusters) is specified by the researcher (here, three), and the clusters are obtained based on the distance between farms in terms of the four size indicators.
} 
Table 1 Descriptive statistics of the data used: 1990-2006

\begin{tabular}{|c|c|c|c|}
\hline Number of observations during the period 1990-2006 & $\begin{array}{l}\text { Field crop farms } \\
27,931\end{array}$ & $\begin{array}{l}\text { Dairy farms } \\
15,953\end{array}$ & $\begin{array}{l}\text { Beef cattle farms } \\
8,142\end{array}$ \\
\hline \multicolumn{4}{|c|}{ Variables used in efficiency and productivity change calculations (farm averages) } \\
\hline Total output (euros) & 110,233 & 86,422 & 52,058 \\
\hline UAA (hectares) & 120.7 & 62.6 & 90.0 \\
\hline Total labour input (AWU) & 1.67 & 1.68 & 1.46 \\
\hline Fixed assets (Euros) & 150,997 & 148,712 & 165,597 \\
\hline Intermediate consumption (Euros) & 67,086 & 50,462 & 35,177 \\
\hline \multicolumn{4}{|l|}{ Other variables } \\
\hline \multicolumn{4}{|l|}{ Farm averages, per year, over 1990-2006 } \\
\hline \multicolumn{4}{|c|}{ Total subsidies (investment, production and rural development subsidies) } \\
\hline In euros & 30,928 & 9,538 & 21,388 \\
\hline As a ratio to total output & 0.338 & 0.108 & 0.466 \\
\hline \multicolumn{4}{|l|}{ 1. Total subsidies on investments } \\
\hline In euros & 366 & 1,039 & 1,030 \\
\hline As a ratio to total output & 0.004 & 0.011 & 0.023 \\
\hline \multicolumn{4}{|c|}{ 2. Total operational subsidies (production and rural development subsidies) } \\
\hline In euros & 30,562 & 8,499 & 20,358 \\
\hline As a ratio to total output & 0.334 & 0.098 & 0.443 \\
\hline \multicolumn{4}{|l|}{ 2.1. Production subsidies } \\
\hline In euros & 30,233 & 6,940 & 17,134 \\
\hline As a ratio to total output & 0.330 & 0.076 & 0.362 \\
\hline \multicolumn{4}{|l|}{ 2.2. Rural development subsidies } \\
\hline In euros & 329 & 1,559 & 3,223 \\
\hline As a ratio to total output & 0.004 & 0.022 & 0.081 \\
\hline Livestock equivalent units & 14.2 & 75.1 & 101.0 \\
\hline UAA per livestock unit (hectares) & - & 0.88 & 0.94 \\
\hline \multicolumn{4}{|l|}{ Shares of farms during 1990-2006 } \\
\hline Share of farms in small-size cluster (\%) & 67.7 & 58.3 & 56.1 \\
\hline Share of farms in medium-size cluster $(\%)$ & 25.6 & 32.1 & 32.9 \\
\hline Share of farms in large-size cluster (\%) & 6.7 & 9.6 & 11.0 \\
\hline Share of farms receiving subsidies on investments (\%) & 7.9 & 14.7 & 18.6 \\
\hline
\end{tabular}

Livestock equivalent units: calculated with the standard EU coefficients applied to each type of livestock on the farm. All monetary values are in real terms

$U A A$ utilised agricultural area, $A W U$ annual working units (1 AWU is equivalent to $2200 \mathrm{~h}$ labour per year)

total subsidies, the field crop sample was the most highly subsidised in terms of value per farm (30,928 euros per farm per year on average). But when related to the value of output, beef cattle farmers received the highest level of subsidies, with an average ratio of 0.466 (vs. 0.338 for field crop farms) indicating that for every euro produced, 0.466 euro in subsidies was received on average. The dairy sample was the least subsidised on average (ratio of 0.108). The same ranking of samples is observed for operational subsidies (i.e. production subsidies plus rural development subsidies) and for production subsidies. By contrast, rural development subsidies were mostly received by beef cattle farms both in value per farm (3223 euros per year) and in relation to the output (a ratio of
0.081). The least subsidised farms in terms of rural development subsidies were field crop farms (329 euros per year and a ratio of 0.004). This is intuitive for two reasons: firstly, during the period studied, agri-environmental schemes in France were mostly designed for livestock farms, which therefore received more AEP; and secondly, field crop farms are mostly located in the plains while LFAs mainly include hilly or mountainous areas, and therefore, crop farms receive less in LFA payments. Investment subsidies accounted for a small share of total subsidies in all three samples. Only $7.9 \%$ of the field crop farms, $14.7 \%$ of the dairy farms and $18.6 \%$ of the beef cattle farms were recipients of investment subsidies during the period considered. 


\section{Results}

\section{Technical efficiency scores and productivity change indices}

As shown in Table 2, during 1990-2006, the field crop sample had on average the lowest TE (average score of 0.499). Dairy farms performed best on average with an average TE of 0.669 , while the average TE score for beef cattle farms was 0.544 . A similar ranking is observed for PTE. In terms of SE, field crop farms and beef cattle farms performed similarly, while dairy farms had the highest average. The low efficiency averages for field crop farms suggest higher heterogeneity among these farms than among livestock farms. This finding conforms to intuition: crop farms tend to have more heterogeneous soil and climatic conditions than do livestock farms, while input quality (in particular land quality) is not captured in the input data used. During the period, the average TE changes were 0.975 , 0.998 and 0.981 , respectively. All change index averages are less than one, suggesting deterioration of the performance during the period studied. However, figures indicate average indices around 0.98 , that is to say an average decrease of $2 \%$ for the yearly scores between 1 year and the next.

Table 3 shows the efficiency score averages during the four periods and results of the tests comparing the scores across the periods. For the field crop sample, the highest efficiency on average (whether TE or PTE) was in the benchmark period (Period 1, during 1990-1994) that is to say before any CAP reform was implemented, followed by a decrease in efficiency during the next period. TE and PTE then decreased again in the next periods, the lowest efficiency averages being attained in 2006 (Period 4), the year where the 2003 CAP reform was implemented with the introduction of the decoupled SFP. By contrast, SE reached its maximum average level during Period 4. Similarly to field crop farms, for both dairy and beef cattle farm samples efficiency (whether TE, PTE or SE) decreased on average following the first CAP reform implementation. All types of efficiency increased again afterwards (Period 3, which is the Agenda 2000 implementation period) for both samples. They decreased again in 2006 (Period 4, which is the 2003 reform implementation) for the dairy farm sample. A small decrease is also observed for PTE for the beef farm sample, but no significant change is observed for TE and SE between Period 3 and Period 4.

Table 4 reports average change indices during the different periods as well as the comparison tests' results. Contrary to that observed in Table 3 for TE and PTE yearly scores whose average in Period 2 was lower than the average in Period 1, the opposite is observed for the change indices in TE and PTE for the three samples: the average changes in TE and PTE increased following the first CAP reform implementation. For example, for the field crop sample, the average TE change was a deterioration of $-3.6 \%$ before the first CAP reform implementation (index average of 0.964 in Period 1) while it was an improvement of $+0.3 \%$ after the first reform's implementation and before the next reform of Agenda 2000 (index average of 1.003 in Period 2). In the third period (following the Agenda 2000 implementation), TE and PTE changes decreased again on average for the field crop and dairy samples (e.g. average deterioration of $-4.1 \%$ for the field crop sample) and remained the same for the beef cattle sample. In contrast to TE and PTE changes, between Periods 1 and 2, technological change worsened substantially for the two livestock samples, going from technological progress for beef cattle farms $(+2.6 \%$ on average) or no change for dairy farm (average index of 1.000) to technological deterioration $(-1.7$ and $-3.1 \%$ on average, respectively). The worsening pattern continued for the beef cattle sample between Periods 2 and 3, while it was held back for the dairy sample with a reduction in technological deterioration from -3.1 to $-1.2 \%$ on average. A contrasting picture is observed for field crop farms, with virtually no change in average technological deterioration between Periods 1 and 2, and a transformation into technological progress (from -3.1 to $+2.7 \%$ on average) between Periods 2 and 3 . As a result, total productivity deterioration was reduced on average for field crop farms (i.e. increase in the Malmquist index average) between Periods 1 and 2, but remained unchanged for the livestock samples. Between Periods 2 and 3, total productivity deterioration worsened for the dairy sample.

\section{The impact of subsidies}

Tables 5 and 6 present the econometric results, for all three samples, of the investigation into the determinants of the three efficiency variables using fixed individual effect regressions and the various productivity change indices using OLS. Regarding the subsidies, results in Table 5 show a variety of effects of these on efficiency: positive, negative and non-significant. The effect of production subsidies on TE and PTE is consistently negative for all three samples. It is also negative on SE for field crop farms, but non-significant for the two livestock samples. Rural development subsidies had no significant effect on TE for all three samples. However, the picture is different when looking at TE's components: such subsidies had no effect on the PTE of both livestock samples, but a positive effect on the PTE of field crop farms; they had a negative effect on the SE of field crop and dairy farms but no effect on the SE of beef farms. Farms that received investment subsidies had a lower TE within the field crop and dairy samples, and a lower PTE within the dairy sample only. The other effects for such subsidies are not significant.

In contrast to Table 5, Table 6 shows that production subsidies had a positive impact on TE change, PTE change and Malmquist total productivity change for field crop and dairy farms (as well on SE change for field crop farms). The other impacts are not significant, except for a negative one on 
Table 2 Average efficiency scores and productivity change indices during 1990-2006

\begin{tabular}{llll}
\hline & $\begin{array}{l}\text { Field crop } \\
\text { farms } \\
27,931\end{array}$ & $\begin{array}{l}\text { Dairy } \\
\text { farms } \\
15,953\end{array}$ & $\begin{array}{l}\text { Beef cattle } \\
\text { farms } \\
8,142\end{array}$ \\
Number of observations for efficiency calculations & & & \\
\hline Average efficiency scores & 0.499 & 0.669 & 0.544 \\
$\quad$ TE score & 0.531 & 0.696 & 0.588 \\
PTE score & 0.928 & 0.952 & 0.922 \\
SE score & 26,338 & 15,175 & 7,604 \\
Number of observations for productivity change & & & \\
$\quad$ calculations & & & 0.998 \\
Average productivity change indices & 0.975 & 0.998 & 0.981 \\
TE change index & 0.976 & 0.997 & 0.989 \\
PTE change index & 0.991 & 0.986 & 0.994 \\
SE change index & 0.997 & 0.986 & 0.983 \\
Technological change index & 0.976 & & \\
Malmquist productivity change index & & & \\
\hline
\end{tabular}

The averages of productivity change indices are the geometrical means technological change for beef cattle farms. Rural development subsidies show either a non-significant impact or a positive impact (for PTE, SE, technological and total productivity changes of field crop farms, and for PTE and total productivity changes of dairy farms). The effect of investment subsidies was almost always not significant; the only exception being for beef cattle farms, whose recipients saw their TE change being worsened.

Other results from the regressions indicate that large farms were the most efficient in the field crop sample and the least efficient in the dairy and beef cattle samples, in terms of TE and PTE (Table 5). This is reversed when looking at PTE change: large farms, along with small farms, had the lowest PTE change in the field crop sample, while they had the highest PTE change in both livestock samples (Table 6). Regarding technological change, it was similar whatever the size cluster in both livestock samples, but highest for small farms in the field crop sample. Table 5 indicates that for both livestock samples, being extensive (i.e. having a large UAA per livestock unit) does not generally favour either TE, PTE or SE (though note that the effect is not significant for the SE beef cattle farms). The effect of extensification degree is generally not significant on change indices, except for a negative effect on SE change and a positive effect on technological

Table 3 Efficiency averages in the different periods, and tests of equality of means between periods

\begin{tabular}{|c|c|c|c|c|c|c|c|c|}
\hline & \multicolumn{4}{|c|}{ Average efficiency score during: } & \multicolumn{4}{|c|}{ Test of equality of means between: } \\
\hline & $\begin{array}{l}\text { Period 1 } \\
\text { 1990-1994 }\end{array}$ & $\begin{array}{l}\text { Period 2 } \\
1995-1999\end{array}$ & $\begin{array}{l}\text { Period } 3 \\
2000-2005\end{array}$ & $\begin{array}{l}\text { Period } 4 \\
2006\end{array}$ & $\begin{array}{l}\text { Periods } \\
1 \text { and } 2\end{array}$ & $\begin{array}{l}\text { Periods } \\
2 \text { and } 3\end{array}$ & $\begin{array}{l}\text { Periods } \\
3 \text { and } 4\end{array}$ & $\begin{array}{l}\text { Periods } \\
1 \text { and } 4\end{array}$ \\
\hline \multicolumn{9}{|c|}{ Field crop farms } \\
\hline $\mathrm{TE}$ & 0.527 & 0.493 & 0.489 & 0.459 & $* * *$ & $*$ & $* * *$ & $* * *$ \\
\hline PTE & 0.555 & 0.526 & 0.523 & 0.486 & $* * *$ & ns & $* * *$ & $* * *$ \\
\hline SE & 0.936 & 0.924 & 0.923 & 0.943 & $* * *$ & ns & $* * *$ & $* * *$ \\
\hline \multicolumn{9}{|c|}{ Dairy farms } \\
\hline $\mathrm{TE}$ & 0.673 & 0.634 & 0.696 & 0.650 & $* * *$ & $* * *$ & $* * *$ & $* * *$ \\
\hline PTE & 0.690 & 0.675 & 0.719 & 0.689 & $* * *$ & $* * *$ & $* * *$ & ns \\
\hline SE & 0.963 & 0.935 & 0.958 & 0.938 & $* * *$ & $* * *$ & $* * *$ & $* * *$ \\
\hline \multicolumn{9}{|c|}{ Beef cattle farms } \\
\hline $\mathrm{TE}$ & 0.577 & 0.520 & 0.540 & 0.529 & $* * *$ & $* * *$ & $\mathrm{~ns}$ & $* * *$ \\
\hline PTE & 0.608 & 0.567 & 0.591 & 0.574 & $* * *$ & $* * *$ & $* *$ & $* * *$ \\
\hline SE & 0.941 & 0.916 & 0.914 & 0.917 & $* * *$ & $* * *$ & $\mathrm{~ns}$ & $* * *$ \\
\hline
\end{tabular}

$t$ tests were performed for TE and PTE, while Mann-Whitney tests were performed for SE

$n s$ difference not significant

$*, * *, * * *$ difference significant at the 10,5 , and $1 \%$ levels, respectively 
Table 4 Average indices in the different periods, and tests of equality of means between periods

\begin{tabular}{|c|c|c|c|c|c|c|}
\hline & \multicolumn{3}{|c|}{$\begin{array}{l}\text { Average change index } \\
\text { during: }\end{array}$} & \multicolumn{3}{|c|}{$\begin{array}{l}\text { Test of equality of } \\
\text { means between: }\end{array}$} \\
\hline & $\begin{array}{l}\text { Period } 1 \\
\text { 1990-1994 }\end{array}$ & $\begin{array}{l}\text { Period } 2 \\
1995-1999\end{array}$ & $\begin{array}{l}\text { Period } 3 \\
2000-2005\end{array}$ & $\begin{array}{l}\text { Periods } \\
1 \text { and } 2\end{array}$ & $\begin{array}{l}\text { Periods } \\
2 \text { and } 3\end{array}$ & $\begin{array}{l}\text { Periods } \\
1 \text { and } 3\end{array}$ \\
\hline \multicolumn{7}{|l|}{ Field crop farms } \\
\hline TE change index & 0.964 & 1.003 & 0.959 & $* * *$ & $* * *$ & ns \\
\hline PTE change index & 0.965 & 1.009 & 0.956 & $* * *$ & $* * *$ & $* *$ \\
\hline SE change index & 0.990 & 0.988 & 0.995 & ns & $* * *$ & $* * *$ \\
\hline Technological change index & 0.978 & 0.979 & 1.027 & ns & $* * *$ & $* * *$ \\
\hline Malmquist productivity change index & 0.946 & 0.987 & 0.990 & $* * *$ & ns & $* * *$ \\
\hline \multicolumn{7}{|l|}{ Dairy farms } \\
\hline TE change index & 0.989 & 1.021 & 0.987 & $* * *$ & $* * *$ & ns \\
\hline PTE change index & 0.990 & 1.016 & 0.991 & $* * *$ & $* * *$ & ns \\
\hline SE change index & 0.996 & 1.002 & 0.992 & $* * *$ & $* * *$ & ns \\
\hline Technological change index & 1.000 & 0.969 & 0.988 & $* * *$ & $* * *$ & $* * *$ \\
\hline Malmquist productivity change index & 0.991 & 0.992 & 0.977 & ns & $* * *$ & $* * *$ \\
\hline \multicolumn{7}{|l|}{ Beef cattle farms } \\
\hline TE change index & 0.947 & 0.997 & 0.997 & $* * *$ & ns & $* * *$ \\
\hline PTE change index & 0.945 & 0.992 & 0.999 & $* * *$ & ns & $* * *$ \\
\hline SE change index & 0.992 & 0.993 & 0.985 & $*$ & $* * *$ & $* * *$ \\
\hline Technological change index & 1.026 & 0.983 & 0.979 & $* * *$ & $* * *$ & $* * *$ \\
\hline Malmquist productivity change index & 0.980 & 0.987 & 0.982 & ns & ns & ns \\
\hline
\end{tabular}

Mann-Whitney tests were performed

$n s$ difference not significant

$*, * *, * * *$ : difference significant at the 10,5 , and $1 \%$ levels, respectively

change for dairy farms (Table 6). Yearly dummies show that TE decreased continuously from 1999 to 2006 for field crop farms and from 1995 to 2004 for beef cattle farms (Table 5). For dairy farms, TE increased from the start of 2000 and did not decrease during the period under consideration. The total productivity change also continuously worsened for field crop farms during the whole period except in 2005-2006 (Table 6). For both livestock samples, the picture is not so smooth, with increases and decreases in total productivity change observed during the period.

\section{Discussion}

The econometric results show a variety of effects from subsidies. Tables 7 and 8 present a summary of the results in terms of the sign of the effect of the three types of subsidy on the three farm samples. The provision of investment subsidies generally has no significant effect, with the exception of a negative effect on field crop farms' TE, dairy farms' TE and PTE and beef cattle farms' TE change. Production subsidies generally have a negative effect on efficiency, except for no significant effect on livestock farms' SE. They had no significant effect on beef cattle farms except for a negative effect on the technical change index. However, they have a positive effect on productivity changes for field crop and dairy farms, except for no significant effect on technological change for both samples and on SE change for dairy farms. Rural development subsidies have no effect on TE and TE change for all three samples. Also, they have no effect on efficiency or change indices for beef cattle farms. For dairy farms, there is only a negative effect on SE and a positive effect on PTE change and on technological change, the rest of the effects being non-significant. As for field crop farms, except for no significant effect on TE and TE change and a negative effect on SE, the other effects are positive.

The finding of so many significant effects of rural development subsidies for field crop farms compared to the livestock sample may be surprising, since the latter received fewer of these subsidies. The low share of field crop farms receiving such subsidies in our sample ( 8 compared to 29 and $54 \%$ for the dairy and beef cattle farm samples, respectively) may be one explanation. Re-running the regressions for the field crop sample, with a dummy variable (taking the value one if the farm received such subsidies and zero otherwise) instead of the value of the subsidies, shows that the positive effect on PTE and on PTE change is confirmed, while the other effects are not significant, except for a new positive effect on TE. 
Table 5 Econometric results of the determinants of efficiency (fixed effect model)

\begin{tabular}{|c|c|c|c|c|c|c|c|c|c|}
\hline & \multicolumn{3}{|c|}{ Field crop farms } & \multicolumn{3}{|l|}{ Dairy farms } & \multicolumn{3}{|c|}{ Beef cattle farms } \\
\hline & $\mathrm{TE}$ & PTE & SE & $\mathrm{TE}$ & PTE & SE & $\mathrm{TE}$ & PTE & SE \\
\hline Dummy $=1$ if year 1991 & $-0.0146 * * *$ & $0.0063 *$ & $-0.0337 * * *$ & $0.0163^{* * *}$ & $0.0092 * * *$ & $0.0093^{* * *}$ & $-0.0481 * * *$ & $-0.0229 * * *$ & $-0.0351 * * *$ \\
\hline Dummy $=1$ if year 1992 & $0.0260 * * *$ & $0.0186^{* * *}$ & $0.0145^{* * *}$ & $0.0138 * * *$ & $0.0072 *$ & $0.0059^{* * *}$ & $-0.0869 * * *$ & $-0.0455^{* * *}$ & $-0.0560 * * *$ \\
\hline Dummy $=1$ if year 1993 & $0.0014^{\mathrm{na}}$ & $0.0187 * * *$ & $-0.0232 * * *$ & $0.0260 * * *$ & $0.0243 * * *$ & 0.0033 & 0.0134 & 0.0070 & $0.0103 *$ \\
\hline Dummy $=1$ if year 1994 & $-0.0231 * * *$ & $-0.0317 * * *$ & $0.0160 * * *$ & $0.0350 * * *$ & $0.0311 * * *$ & $0.0073^{* * *}$ & $0.0340 * * *$ & $0.0225^{* *}$ & $0.0155^{* *}$ \\
\hline Dummy $=1$ if year 1995 & $-0.0280 * * *$ & $-0.0233 * * *$ & $-0.0030^{\mathrm{na}}$ & $-0.0083 * *$ & $0.0100^{* *}$ & $-0.0225 * * *$ & $-0.0764 * * *$ & $-0.0420 * * *$ & $-0.0487 * * *$ \\
\hline Dummy $=1$ if year 1996 & $-0.0710 * * *$ & $-0.0572 * * *$ & $-0.0207 * * *$ & $0.0177 * * *$ & $0.0417 * * *$ & $-0.0259 * * *$ & $-0.0551 * * *$ & $-0.0427 * * *$ & $-0.0208 * * *$ \\
\hline Dummy $=1$ if year 1997 & $0.0041^{\text {na }}$ & $0.0135 * *$ & $-0.0122 * * *$ & -0.0004 & 0.0039 & -0.0016 & $-0.0919 * * *$ & $-0.0810^{* * *}$ & $-0.0291 * * *$ \\
\hline Dummy $=1$ if year 1998 & $-0.0033^{\text {na }}$ & $0.0121 * *$ & $-0.0254 * * *$ & $-0.0549 * * *$ & $-0.0363 * * *$ & $-0.0275^{* * *}$ & $-0.0506 * * *$ & $-0.0251 * *$ & $-0.0368 * * *$ \\
\hline Dummy = 1 if year 1999 & $-0.0229 * * *$ & $-0.0191 * * *$ & $-0.0111 * * *$ & $-0.0528 * * *$ & $-0.0284 * * *$ & $-0.0314 * * *$ & $-0.1016^{* * *}$ & $-0.0829 * * *$ & $-0.0316 * * *$ \\
\hline Dummy $=1$ if year 2000 & $-0.0202 * * *$ & $0.0005^{\text {na }}$ & $-0.0317 * * *$ & $0.0299 * * *$ & $0.0262 * * *$ & $0.0059 * *$ & $-0.1023 * * *$ & $-0.0821 * * *$ & $-0.0383 * * *$ \\
\hline Dummy $=1$ if year 2001 & $-0.0559 * * *$ & $-0.0491 * * *$ & $-0.0170^{* * *}$ & $0.0277 * * *$ & $0.0250 * * *$ & 0.0033 & $-0.0838 * * *$ & $-0.0683 * * *$ & $-0.0235 * * *$ \\
\hline Dummy $=1$ if year 2002 & $-0.0587 * * *$ & $-0.0328 * * *$ & $-0.0394 * * *$ & $0.0758 * * *$ & $0.0592 * * *$ & $0.0172 * * *$ & $-0.0702 * * *$ & $-0.0349 * * *$ & $-0.0439 * * *$ \\
\hline Dummy $=1$ if year 2003 & $-0.0621 * * *$ & $-0.0534 * * *$ & $-0.0200^{* * *}$ & $0.0462 * * *$ & $0.0490 * * *$ & $-0.0066^{* *}$ & $-0.0730 * * *$ & $-0.0414 * * *$ & $-0.0637 * * *$ \\
\hline Dummy $=1$ if year 2004 & $-0.0231 * * *$ & $-0.0201 * * *$ & $-0.0045^{\mathrm{na}}$ & $0.0414 * * *$ & $0.0284 * * *$ & $0.0128^{* * *}$ & $-0.0640 * * *$ & $-0.0363 * * *$ & $-0.0297 * * *$ \\
\hline Dummy $=1$ if year 2005 & $-0.0300 * * *$ & $-0.0359 * * *$ & $0.0131 * * *$ & 0.0021 & $0.0108^{* *}$ & $-0.0157 * * *$ & $0.0373 * * *$ & $0.0311 * *$ & 0.0063 \\
\hline Dummy $=1$ if year 2006 & $-0.0769 * * *$ & $-0.0746^{* * *}$ & $0.0026^{\text {na }}$ & 0.0024 & $0.0154 * * *$ & $-0.0185 * * *$ & $-0.0679 * * *$ & $-0.0552 * * *$ & $-0.0282 * * *$ \\
\hline $\begin{array}{l}\text { Dummy }=1 \text { if farm } \\
\text { received investment } \\
\text { subsidies }\end{array}$ & $-0.0035^{*}$ & $-0.0030^{\mathrm{na}}$ & $-0.0007^{\mathrm{na}}$ & $-0.0077^{* * *}$ & $-0.0071 * * *$ & -0.0008 & -0.0014 & -0.0019 & 0.0004 \\
\hline $\begin{array}{l}\text { Value received of } \\
\text { production subsidies } \\
\text { per hectare of UAA or } \\
\text { per livestock unit }\end{array}$ & $-0.2131 * * *$ & $-0.2060^{* * *}$ & $-0.0418^{* * *}$ & $-0.1102 * * *$ & $-0.1171 * * *$ & 0.0086 & $-0.1052 * * *$ & $-0.0803^{* *}$ & -0.0334 \\
\hline $\begin{array}{l}\text { Value received of rural } \\
\text { development } \\
\text { subsidies per hectare } \\
\text { of UAA or per } \\
\text { livestock unit }\end{array}$ & $-0.0010^{\mathrm{na}}$ & $0.0963 *$ & $-0.1720^{* * *}$ & -0.0176 & 0.0286 & $-0.0513^{* * *}$ & -0.0297 & -0.0051 & -0.0536 \\
\hline UAA per livestock unit & & & & $-2.7314 * * *$ & $-2.5179 * * *$ & $-0.7036^{*}$ & $-3.0216^{* * *}$ & $-2.6596^{* *}$ & -0.7883 \\
\hline $\begin{array}{l}\text { Dummy }=1 \text { if farm in } \\
\text { medium-size cluster } \\
\text { and } 0 \text { otherwise }\end{array}$ & $-0.0247 * * *$ & $-0.0278 * * *$ & $0.0045^{* *}$ & $-0.0172 * * *$ & $-0.0191 * * *$ & 0.0032 & -0.0029 & -0.0016 & 0.0010 \\
\hline $\begin{array}{l}\text { Dummy }=1 \text { if farm in } \\
\text { large-size cluster and } \\
0 \text { otherwise }\end{array}$ & $0.0095 * *$ & $0.0050^{\text {na }}$ & $0.0084 * *$ & $-0.0357 * * *$ & $-0.0220 * * *$ & $-0.0188 * * *$ & $-0.0343 * * *$ & -0.0001 & $-0.0474 * * *$ \\
\hline Number of observations & 27,931 & 27,931 & 27,931 & 15,953 & 15,953 & 15,953 & 8142 & 8142 & 8142 \\
\hline$R$ square & 0.2076 & 0.1746 & 0.0828 & 0.1808 & 0.1050 & 0.1166 & 0.1774 & 0.0959 & 0.1112 \\
\hline Model's $F$ statistic & $290.1 * * *$ & $234.4 * * *$ & $100.0 * * *$ & $127.3 * * *$ & $67.7 * * *$ & $76.1 * * *$ & $62.8 * * *$ & $30.9 * * *$ & $36.4 * * *$ \\
\hline $\begin{array}{l}F \text { test of absence of fixed } \\
\text { effects }\end{array}$ & $11.7^{* * *}$ & $10.9^{* * *}$ & $5.7 * * *$ & $6.8 * * *$ & $6.7 * * *$ & $4.2 * * *$ & $5.0^{* * *}$ & $4.6^{* * *}$ & $3.2 * * *$ \\
\hline
\end{tabular}

Results for the regional dummies are not shown. The value of subsidies is per hectare of UAA for the field crop sample and per livestock unit for the dairy and beef cattle samples

n.a not applicable

$*, * *, * * *$ significance at the 10,5 and $1 \%$ levels, respectively

The fact that production subsidies have a consistently negative effect on TE and PTE for all three samples confirms the literature's general finding. As explained above, one explanation may be farmers' reduced effort, as suggested by Martin and Page (1983) or a change in farmers' risk attitudes (Serra et al., 2008). However, another explanation might be that farmers implement changes in their practices that lead to a reduction in their efficiency in the same year, but that enable improving efficiency over time. This is suggested by the positive effect of production subsidies on efficiency changes and 


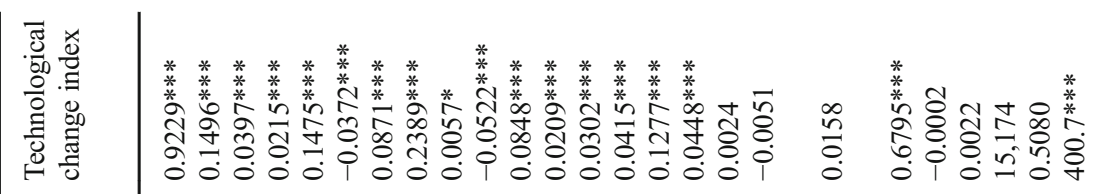

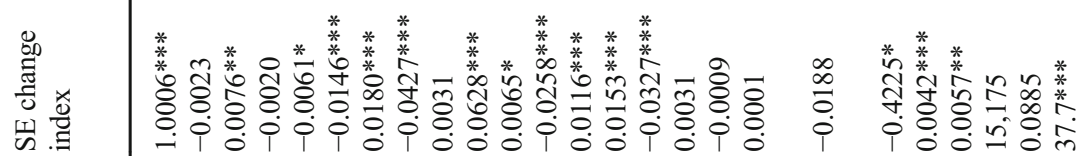

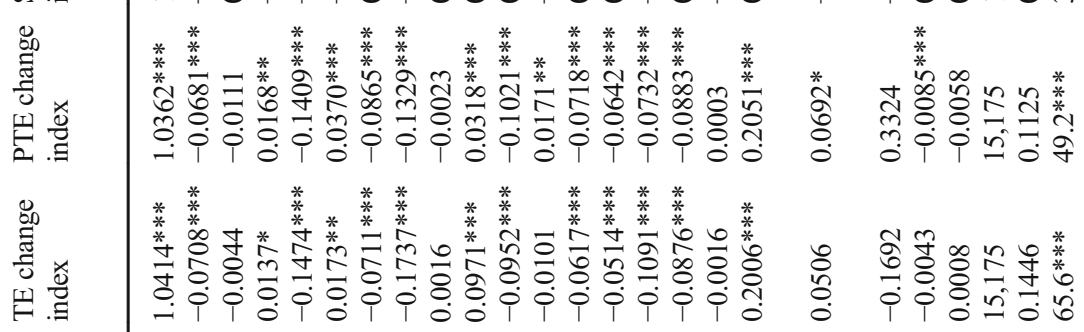

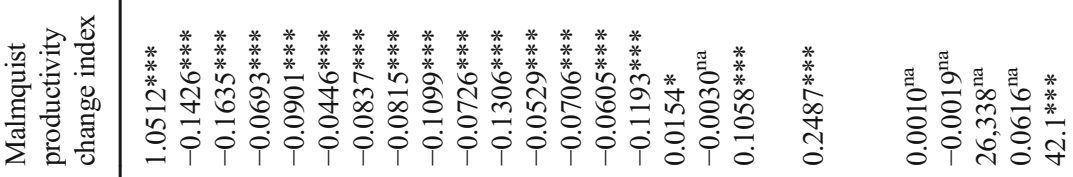

तี

苞

긍

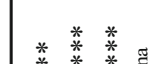

$* * *$

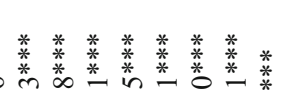

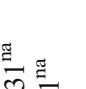

$\stackrel{*}{*}$

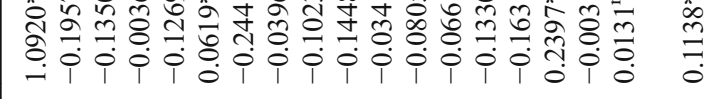

菜草草草

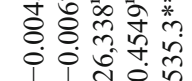

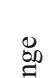

密

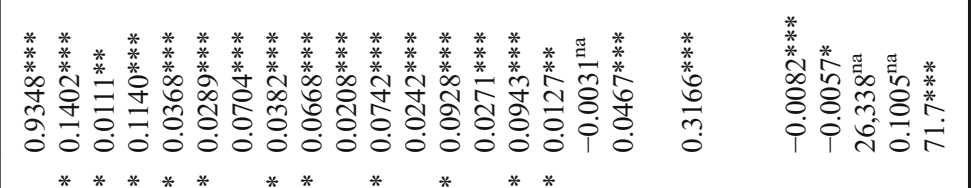
焉.

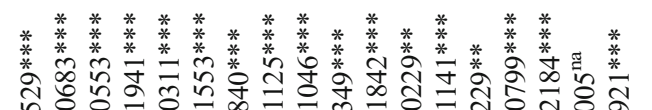

$\stackrel{80}{*}$

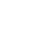

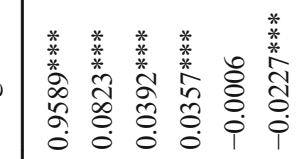

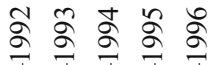

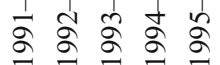

$\bar{\nabla} \cdot \overline{0} \quad \overline{0} . \bar{\circ}$

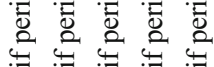

II $\|\pi\|$

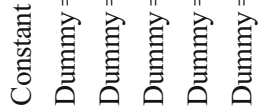




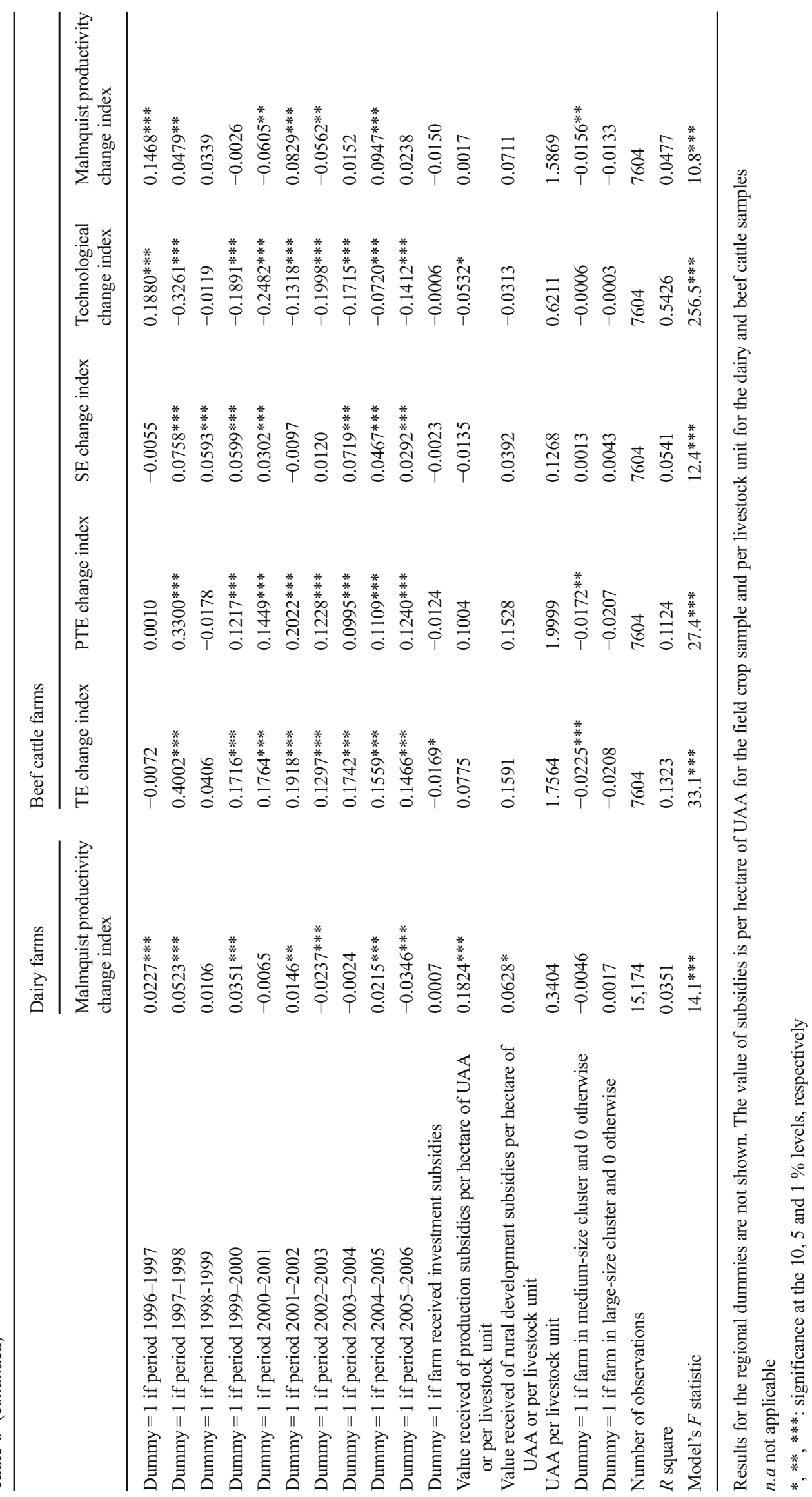


Table 7 Summary of the effect of subsidies on farms' efficiency scores

\begin{tabular}{llll}
\hline & TE & PTE & SE \\
\hline Investment subsidies & & & \\
$\quad$ Field crop farms & - & n.s. & n.s. \\
Dairy farms & - & - & n.s. \\
Beef cattle farms & n.s. & n.s. & n.s. \\
Production subsidies & & & \\
Field crop farms & - & - & - \\
Dairy farms & - & - & n.s. \\
Beef cattle farms & - & - & n.s. \\
Rural development subsidies & & & \\
Field crop farms & n.s. & + & - \\
Dairy farms & n.s. & n.s. & - \\
Beef cattle farms & n.s. & n.s. & n.s. \\
\hline
\end{tabular}

,+- , n.s.: effect of the subsidies on efficiency is positive, negative and not significant, respectively

total productivity changes for field crop and dairy farms, as found by Guyomard et al. (2006) and Zheng and Kening (2011). Production subsidies, which can be considered as additional cash flow to the farms, may help farmers by lifting their financial constraints and thus allowing them to purchase different inputs that lead, over the longer term, to higher efficiency.

Being a recipient of investment subsidies was not found to favour efficiency, but rather had a negative impact for field crop and dairy farms and no significant impact for beef cattle farms. The impact is also consistently not significant on the year-to-year efficiency change, technological and productivity change (except for a negative impact on TE change for beef cattle farms). One reason for such negative or non-significant effects may be that, while such subsidies are used to implement new technology, acquiring the know - how to use this technology in an efficient way takes time. However, it should also be mentioned here that some effects are found to be different if the value of subsidies is considered in the explanatory variables, instead of the dummy indicating whether the farm has received non-zero subsidies. The effect of the value of subsidies is not significant for all efficiency variables and all samples. Also, the negative effect identified on TE change for beef cattle farms is not significant with the subsidy values. By contrast, the effect on total productivity change for field crop farms becomes significant, the sign being positive.

\section{Conclusion}

This paper contributes to the literature on the efficiencysubsidy relationship, by empirically investigating the effects of three types of subsidies (investment subsidies, production subsidies and rural development subsidies) on French farms' TE and productivity change during the period 1990-2006 for three types of farms: field crop farms, dairy farms and beef cattle farms.

Several main findings can be highlighted. First, following the first CAP reform implementation (the 1992 MacSharry reform) when area and livestock headage payments were introduced for the first time, efficiency for all three farm samples considered decreased on average. By contrast, efficiency change improved on average. Technological change worsened for both livestock samples but remained unchanged for field crop farms on average. As a result, total productivity change improved for field crop farms and remained unchanged for both livestock samples. These observations suggest that limiting the investigation of the effect of public subsidies to

Table 8 Summary of the effect of subsidies on farms' productivity change indices

\begin{tabular}{|c|c|c|c|c|c|}
\hline & TE change index & PTE change index & SE change index & $\begin{array}{l}\text { Technological } \\
\text { change index }\end{array}$ & $\begin{array}{l}\text { Malmquist productivity } \\
\text { change index }\end{array}$ \\
\hline \multicolumn{6}{|l|}{ Investment subsidies } \\
\hline Field crop farms & n.s. & n.s. & n.s. & n.s. & n.s. \\
\hline Dairy farms & n.s. & n.s. & n.s. & n.s. & n.s. \\
\hline Beef cattle farms & - & n.s. & n.s. & n.s. & n.s. \\
\hline \multicolumn{6}{|l|}{ Production subsidies } \\
\hline Field crop farms & + & + & + & n.s. & + \\
\hline Dairy farms & + & + & n.s. & n.s. & + \\
\hline Beef cattle farms & n.s. & n.s. & n.s. & - & n.s. \\
\hline \multicolumn{6}{|c|}{ Rural development subsidies } \\
\hline Field crop farms & n.s. & + & + & + & + \\
\hline Dairy farms & n.s. & + & n.s. & n.s. & + \\
\hline Beef cattle farms & n.s. & n.s. & n.s. & n.s. & n.s. \\
\hline
\end{tabular}

,,+- n.s.: effect of the subsidies on efficiency is positive, negative, and not significant, respectively 
yearly efficiency may provide a narrow picture, and that analyses need to be carried out in a broader way. There are two ways of achieving this: (i) by investigating longer periods: while short term results may show a deterioration of farms' performance, in the longer term the effects may be positive; (ii) by investigating several dimensions of performance, namely yearly efficiency, efficiency change and total productivity change.

Second, econometric results regarding the effect of subsidies are ambiguous. The effect of a particular type of subsidy was found not significant, negative or positive depending on the sample's production specialisation and on the efficiency variable considered, confirming Serra et al. (2008) suggestion and Minviel and Latruffe (2014) meta-analysis results on various analysis contexts. Therefore, our findings highlight the fact that systemic policy recommendations cannot be drawn without a precise context specification. For example, the impact of a policy on farms with a given production specialisation may differ from the impact on other types of farms, suggesting that it may not be possible to generalise conclusions drawn from analyses on one production sector to the whole farming sector.

Third, receiving investment subsidies was found to favour neither a farm's yearly efficiency nor year-to-year productivity change. This suggests a necessary delay between the moment where subsidies are received (and the new technology implemented), and the moment where the new technology is fully operational. From a methodological point of view, it may therefore be more relevant to assess the effect of past (instead of current) investment subsidies on current or future efficiency.

Fourth, our findings regarding production subsidies confirm the existing literature about a decrease in efficiency due to such subsidies, but point to a positive effect on efficiency and productivity changes. This suggests that such subsidies may enable farmers to relax their financial constraints and purchase inputs that can make a difference to the output achieved the following year. Hence, while most of the efficiency-subsidy research has focused on the immediate effect of subsidies, we recommend that further empirical research is undertaken regarding the effect of subsidies on TE change to confirm or contradict such findings.

Fifth, the results regarding rural development subsidies (namely LFA payments and AEP) show a complex picture, with many non-significant effects, some positive effects and a few negative effects. LFA payments, granted to farms solely because they are located in unfavourable agroecological areas, may therefore keep inefficient farms in the sector. However, by favouring the presence of farms, these subsidies may help maintain agricultural land in good conditions in such areas. AEP are provided when environmental-friendly practices are implemented on the farm, which may necessitate additional labour while no increase in output is generated. Therefore, a methodological suggestion for future research would be to include an environmental output when calculating efficiency and investigating the effect of rural development subsidies on such efficiency.

Finally, modelling the subsidies either as the value received by the farm, or as a dummy variable capturing whether the farm was a recipient or not, may not provide the same findings. This was evident here for investment subsidies, and for rural development subsidies in the case of field crop farms. The effect may change from significant to non-significant and, inversely, a non-significant effect may become significantly positive. This suggests a selection effect, and Heckman models could be used in future research, where the effect of subsidies is investigated in two stages: on receiving the subsidies, and on the efficiency of the subsidies' recipients. Threshold effects may also be investigated, that is to say the level of subsidies that triggers an effect on efficiency.

Acknowledgments The research leading to these results has received funding from the European Community's Seventh Framework Programme (FP7/2007-2013) under grant agreement no. 212292 (FACEPA). The authors are grateful to Boris Bravo-Ureta for his valuable comments.

Open Access This article is distributed under the terms of the Creative Commons Attribution 4.0 International License (http:// creativecommons.org/licenses/by/4.0/), which permits unrestricted use, distribution, and reproduction in any medium, provided you give appropriate credit to the original author(s) and the source, provide a link to the Creative Commons license, and indicate if changes were made.

\section{References}

Bakucs LZ, Latruffe L, Fertõ I, Fogarasi J (2010) The impact of EU accession on farms' technical efficiency in Hungary. PostCommunist Economies 22(2):165-175

Bergström F (2000) Capital subsidies and the performance of firms. Small Business Economics 14(3):183-193

Bojnec S, Latruffe L (2009) Determinants of technical efficiency of Slovenian farms. Post-Communist Economies 21(1):117-124

Carlin T, Crecink J (1979) Small farm definition and public policy. American Journal of Agricultural Economics 61(5):933-939

Carroll J, Greene S, O'Donoghue C, Newman C, Thorne F (2009) Productivity and the determinants of efficiency in Irish agriculture (1996-2006), 83rd annual conference. Agricultural Economics Society, Dublin, p 30

Caves D, Christensen L, Diewert E (1982) The economic theory of index numbers and the measurement of input, output, and productivity. Econometrica 50(6):1393-1414

Charnes A, Cooper W, Rhodes E (1978) Measuring the efficiency of decision making units. European Journal of Operational Research 2(6):429-444

Coelli T, Perelman S, van Lierde D (2006) CAP reforms and total factor productivity growth in Belgian agriculture: a Malmquist index approach, 26th conference of the International Association of Agricultural Economists (IAAE), August 12-18. Queensland, Australia, p 20 
Emvalomatis G, Oude LA, Stefanou S (2008) An examination of the relationship between subsidies on production and technical efficiency in agriculture: the case of cotton producers in Greece, $107^{\text {th }}$ EAAE seminar 'Modelling of Agricultural and Rural Development Policies', January 30-February 1. Sevilla, Spain, p 16

Färe R, Grosskopf S, Lindgren B, Roos P (1992) Productivity changes in Swedish pharmacies 1980-1989: a non-parametric approach. Journal of Productivity Analysis 3(1-2):85-101

Farrell M (1957) The measurement of productive efficiency. Journal of the Royal Statistical Society 120(3):253-290

Giannakas K, Schoney R, Tzouvelekas V (2001) Technical efficiency, technological change and output growth of wheat farms in Saskatchewan. Canadian Journal of Agricultural Economics 49(2): $135-152$

Guyomard H, Latruffe L, Le Mouël C (2006) Technical efficiency, technical progress and productivity change in French agriculture: Do subsidies and farms' size matter?, 96th EAAE Seminar, January 10-11, Tänikon, Switzerland, $\mathrm{p} 18$

Hadley D (2006) Patterns in technical efficiency and technical change at the farm-level in England and Wales, 1982-2002. Journal of Agricultural Economics 57(1):81-100

Kumbhakar S, Lien G, Hardaker B (2014) Technical efficiency in competing panel data models: a study of Norwegian grain farming. Journal of Productivity Analysis 41(2):321-337

Lachaal L (1994) Subsidies, endogenous technical efficiency and the measurement of productivity growth. Journal of Agricultural and Applied Economics 26(1):299-310

Latruffe L, Davidova S, Balcombe K (2008) Application of a double bootstrap to investigation of determinants of technical efficiency of farms in Central Europe. Journal of Productivity Analysis 29(2): 183-191

Latruffe L, Fogarasi J (2009) Farm performance and support in Central and Western Europe: a comparison of Hungary and France, Working paper SMART-LERECO, No 09-07. Rennes, France, p 23

Lund P (1983) The use of alternative measures of farm size in analysing the size and efficiency relationship. Journal of Agricultural Economics 34(2):187-189

Martin J, Page J (1983) The impact of subsidies on X-efficiency in LDC industry: theory and empirical test. The Review of Economics and Statistics 65(4):608-617

Mary S (2013) Assessing the impacts of pillar 1 and 2 subsidies on TFP in French crop farms. Journal of Agricultural Economics 64(1):133144

Minviel JJ, Latruffe L (2014) Meta-regression analysis of the impact of agricultural subsidies on farm technical efficiency, EAAE 2014
Congress 'Agri-Food and Rural Innovations for Healthier Societies', August 26-29. Ljubljana, Slovenia, p 12

Nastis S, Papanagiotou E, Zamanidis S (2012) Productive efficiency of subsidized organic alfalfa farms. Journal of Agricultural and Resource Economics 37(2):280-288

Paul CJM, Johnston W, Frengley G (2000) Efficiency in New Zealand sheep and beef farming: the impacts of regulatory reform. The Review of Economics and Statistics 82(2):325-337

Rezitis AN, Tsiboukas K, Tsoukalas S (2003) Investigation of factors influencing the technical efficiency of agricultural producers participating in farm credit programs: the case of Greece. Journal of Agricultural and Applied Economics 35(3):529-542

Rizov M, Pokrivcak J, Ciaian P (2013) CAP subsidies and productivity of the EU farms. Journal of Agricultural Economics 64(3):537-557

Serra T, Zilberman D, Gil JM (2008) Farms' technical inefficiencies in the presence of government programs. Australian Journal of Agricultural and Resource Economics 52(1):57-76

Simar L, Wilson PW (1998) Sensitivity analysis of efficiency scores: how to bootstrap in nonparametric frontier models. Management Science 44(1):49-61

Simar L, Wilson PW (1999) Estimating and bootstrapping Malmquist indices. European Journal of Operational Research 115(3):459-471

Simar L, Wilson PW (2000) Statistical inference in nonparametric frontier models: the state of the art. Journal of Productivity Analysis 13(1): 49-78

Simar L, Wilson PW (2007) Estimation and inference in two-stage, semiparametric models of production processes. Journal of Econometrics 136(1):31-64

Sipiläinen T, Kumbhakar SC, Lien G (2014) Performance of dairy farms in Finland and Norway from 1991 to 2008. European Review of Agricultural Economics 41(1):63-86

Wilson PW (1993) Detecting outliers in deterministic nonparametric frontier models with multiple outputs. Journal of Business and Economic Statistics 11(3):319-323

Zheng L, Kening W (2011) Productivity change and agricultural policy reform in China: village level evidence for 1995 to 2009, 2011 AAEA \& NAREA joint annual meeting, July 24-26. Pittsburgh, U.S.A., p 22

Zhu X, Karagiannis G, Oude LA (2011) The impact of direct income transfers of CAP on Greek olive farms' performance: using a nonmonotonic inefficiency effects model. Journal of Agricultural Economics 62(3):630-638

Zhu X, Oude LA (2010) Impact of CAP subsidies on technical efficiency of crop farms in Germany, the Netherlands and Sweden. Journal of Agricultural Economics 61(3):545-564 